\title{
KONSEP EKONOMI KERAKYATAN BERBASIS HUKUM TRANSENDENTAL
}

\author{
Ratna Riyanti', Maheswara Edi Harnantio² \\ ${ }^{1}$ Universitas Pahlawan Tuanku Tambusai Riau \\ ${ }^{2}$ Universitas Pancasakti Tegal \\ Email: ratnariyanti662@gmail.com
}

\begin{abstract}
Abstrak
Sistem ekonomi yang berlandaskan paradigma nilai-nilai Pancasila, menempatkan kedaulatan rakyat sebagai Khalifah Allah SWT di muka bumi, berorientasi pada kemaslahatan bersama inilah yang dimaksud dengan Ekonomi kerakyatan (demokrasi ekonomi). Ada perbedaan mendasar antara sistem ekonomi di negara yang menganut demokrasi liberal-kapitalis maupun demokrasi sosialis Ekonomi kerakyatan ini berlandaskan Pancasila dan merupakan perekonomian yang dikembangkan dengan bingkai nilai-nilai spiritual seperti nilai Ketuhanan (Tauhid). Kemunculan investor-investor politik yang kepentingan terakomodasi dari sistem transaksional, termasuk adanya hegemoni kapitalisme yang berpengaruh dengan adanya globalisasi sehingga menyebabkan pasar di pusat keuangan menerobos batas-batas nasional hal merupakan penerapan sistem demokrasi ekonomi yang keluar dari nilai dan paradigma Pancasila. Hal ini merupakan permasalahan ideologis, sehingga dimensi transendental dalam ekonomi kerakyatan perlu ditumbuhkan kembali untuk memerangi ancaman arus globalisasi dan kapitalisme bentuk baru (neoliberal), dengan mengembalikan tata nilai transendensi Pancasila kedalam bangunan sistem ekonomi, hukum dan politik di Indonesia.
\end{abstract}

Kata Kunci: Ekonomi Kerakyatan, Demokrasi, Transendental.

\begin{abstract}
An economic system based on the paradigm of Pancasila values, placing the position of the people as the Caliph of Allah SWT on earth, oriented to the common good is what is meant by People's Economy (economic democracy). There is a fundamental difference between the economic system in a country that adheres to a liberal-capitalist democracy and a socialist democracy, the Pancasila populist economy, and an economy that is developed within the framework of spiritual values such as the value of divinity (Tawhid). The emergence of political investors whose interests are accommodated from the transactional system, including the hegemony of capitalism which has an effect on globalization, causing the market in the financial center of national boundaries, is the application of a democratic system that comes out of the values and paradigms of Pancasila. This is an ideological problem, so that the transcendental dimension in the populist economy needs to be re-grown to fight the threat of globalization and new forms of capitalism, by restoring the transcendent values of Pancasila into the building of economic, legal and political systems in Indonesia.
\end{abstract}

Keywords: People's Economy, Democracy, Transcendental. 


\section{A. PENDAHULUAN}

Kekuasaan sebuah negara pada intinya perlu diatur dan dibatasi oleh sebuah Konstitusi karena Konstitusi memuat tidak hanya sistem politik saja tetapi juga memuat sistem ekonomi, arah dan orientasi ekonomi suatu bangsa. Jimly Asshiddiqie menyebutkan bahwa UUD 1945 adalah konstitusi ekonomi Indonesia karena didalamnya memuat dokumen ekonomi yaitu dalam Pasal 33 UUD 1945 (Asshiddiqie, 2010). Konstitusi ekonomi memuat dokumen-dokumen ekonomi yang disepakati oleh para pendiri bangsa setelah sebelumnya melalui sejumlah proses dan perdebatan panjang dengan segala arus pemikiran yang mempengaruhinya. Arief Sidharta sebagaimana dikutip oleh Jazim Jumadi menyebutkan bahwa proklamasi pada tanggal 17 Agustus 1945 merupakan sebuah tindakan hukum revolusioner yang memunculkan keberadaan negara RI. Makna tindakan hukum disini adalah tindakan pengaturan yang sekali selesai (einmahlig) dimana implikasinya membawa perubahan sistem hukum dan perubahan status politik. Dengan proklamasi tersebut terbentuklah sebuah negara baru yakni negara Indonesia yang merdeka dan dengan itu tatanan sistem hukum kolonial Hindia Belanda terhapus dengan sendirinya, diatasnya terbentuk tatanan hukum baru (Jumadi, 2016).

Proklamasi kemerdekaan lebih berorientasi pada lingkup pengertian hukum, yaitu proklamasi kemerdekaan merupakan sarana hukum untuk mengumumkan kepada dunia bahwa Indonesia telah merdeka. Konsekuensi hukumnya, negara Indonesia telah berdiri dan berdaulat (de facto dan de jure), serta telah menjadi subyek hukum yang memiliki derajat sama tinggi dengan negara-negara merdeka di belahan dunia yang lain. Kemerdekaan kita yang diakui oleh segala bangsa. Proklamasi pada waktu itu berlaku bagi kita sendiri, sebagaikebulatan tekad untuk hidup sebagai bangsa yang merdeka ditengah-tengah bangsa lain (Yamin, 1997).

Ideologi mempunyai peranan yang sangat penting dalam kehidupan bernegara. Ideologi ini merupakan adalah suatu ruh, nafas dan falsafah sebuah bangsa. Jorge Larrain dalam tulisannya tentang The Concept of Idelogy (2002) yang dikutip oleh Payerli Pasaribu menyebutkan bahwa "Ideologi as a set of beliefs" yaitu setiap individu atau kelompok masyarakat memiliki suatu sistem kepercayaan mengenal sesuatu yang dipandang bernilai dan menjadi kekuatan motivasi bagi perilaku individu atau kelompok masyarakat. Nilai-nilai yang dipandang itu sebagai cita-cita yang menjadi landasan bagi cara pandang, cara fikir dan cara tindak seseorang atau bangsa dalam menyelesaikan masalah-masalah yang dihadapinya. Dengan demikian, ideologi dipahami sebagai seperangkat sistem nilai yang diyakini kebenarannya oleh suatu bangsa dan digunakan sebagai dasar untuk menata masyarakat dalam negara. Ideologi mengandung nilai-nilai dasar yang hidup dalam masyarakatnya dan terkristalisasi dalam falsafah negara (Pasaribu, 2015).

Konsep negara kesejahteraan (welfare state) menjadi insprasi founding fathers dalam merumuskan Pasal 33 UUD 1945, hal tersebut ditunjukkan dari bagian tujuan negara yang menyebutkan bahwa negara bertujuan melindungi segenap bangsa dan seluruh tumpah darah Indonesia, mencerdaskan kehidupan bangsa, memajukan kesejahteraan umum, dan ikut melaksanakan ketertiban dunia berdasar perdamaian abadi; sedangkan pada bagian dasar negara, Pancasila, ditegaskan di dalam sila kelima, "Keadilan sosial bagi seluruh rakyat Indonesia". Dalam bidang hukum administrasi konsep negara kesejahteraan melahirkan 
"freies Ermessen" yakni berbagai kewenangan untuk melakukan langkah-langkah yang dilindungi oleh konstitusi guna membangun kesejahteraan umum. Melalui freies Ermessen Pemerintah mempunyai kewenangan inisiatif, kewenangan delegatif, dan droit function (menafsirkan secara sepihak) (Mahfud M D, 2016).

Kemerdekaan memiliki makna sebagai kebebasan, termasuk kebebasan sebuah negara untuk mengatur segala hal, seperti memilih dan menyepakati ideologi. Ideologi yang mendominasi dunia pada saat itu adalah ideologi yang bersumber dari aliran positivistik. Ideologi yang dianut di negara-negara Eropa Kontinental yang ratusan tahun menjajah Indonesia juga berakar pada pemahaman positivisme dengan menjadikan supremasi rakyat sebagai segala-galanya. Sistem demokrasi adalah sistem politik yang tengah mendominasi, akar demokrasi adalah positivisme. Demokrasi yang mempengaruhi Indonesia di awal kemerdekaannya adalah demokrasi liberal (Amerika dan sebagian Eropa) serta demokrasi sosialis (Uni Soviet dan Negara dengan ideologi kiri).

Para pendiri bangsa menyepakati untuk mengembangkan demokrasi dengan ciri khas tersendiri yang kemudian dikenal dengan terminologi Demokrasi Pancasila. Kelaziman untuk membangun bangsa yang berdaulat pastilah membutuhkan ideologi sebagai falsafah bernegara. Ideologi menjadi pedoman sebuah bangsa atau sebuah negara dalam menjalankan pemerintahan atau berinteraksi. Rumusan awal Pancasila disampaikan pertama kali oleh Bung Karno saat mendapatkan kesempatan untuk menyampaikan pidato dihadapan sidang BPUPKI pada tanggal 1 Juni 1945. Pidato tersebut disampaikan oleh Bung Karno secara langsung tanpa teks yang akhirnya secara aklamasi disepakati sebagai lahirnya Pancasila. Rumusan Pancasila tersebut disempurnakan oleh tim kecil yang disebut Panitia Sembilan, terdiri dari sembilan tokoh dengan latar belakang dari kelompok nasionalis sekuler dan nasionalis Islam. Sembilan tokoh tersebut adalah: Ir. Soekarno, Drs. Moh Hatta, AA Maramis, Abikoesno Tjokrosoejoso, Abdul Kahar Muzakir, Agus Salim, Achmad Soebardjo, Wahid Hasjim dan Mohchammad Yamin.Konstitusi kita telah menggariskan konsep ekonomi kerakyatan sebagai landasan ideologi ekonomi bangsa, dalam UUD 1945 Amandemen ke-4 terminologi ekonomi kerakyatan ini disebut dengan demokrasi ekonomi, sebuah sistem ekonomi yang mengedepankan prinsip kebersamaan, efisiensi berkeadilan, berkelanjutan, berwawasan lingkungan, kemandirian serta dengan menjaga keseimbangan kemajuan dan kesatuan ekonomi nasional (Yunus, 2018). Konstitusi ekonomi dengan mendasarkan pada demokrasi ekonomi adalah sistem ekonomi jalan tengah, tidak liberal kapitalistik dan tidak sosialis, tapi sistem ekonomi yang berakar pada Pancasila, ciri khas bangsa Indonesia.

Berdasarkan uraian diatas, penulis tertarik untuk mengakji tentang dimensi transendental dalam ekonomi kerakyatan (demokrasi ekonomi) sebagai ideologi ekonomi Indonesia yang berbeda dengan sistem ekonomi di negara-negara demokratis lain yang berakar pada dominasi positivisme dengan segala permasalahannya yang terbukti tidak dapat memberikan solusi terhadap berbagai persoalan kehidupan.

\section{B. PEMBAHASAN}

\section{Transendendi Konstitusi}

Pemikiran transendental dapat dilihat pada nilai nilai agama, spiritual, etika, dan moralitas yang penuh dengan dinamika dan pergumulan pemikiran yang lahir dalam rentang 
sejarah yang panjang. Ilmu modern yang selama ini berada dalam koridor hegemoni modernis-positivistik dengan doktin empiris, objektivis, dan rasional mulai digugat kaum pemikir transendental yang lebih mengedepankan nilai dan makna dibalik itu, sehingga tampak bangunan ilmu yang menjadi lebih terbuka dan utuh dalam merespon persoalan hidup dan kehidupan. Dalam hal ini, pemikiran transendental mulai mengangkat hal-hal yang sifatnya irasional dan metafisika (emosi, perasaan, intuisi, nilai, pengalaman personal, spekulasi), moral, dan spiritual sebagai bagian integral dalam memahami keilmuan (Absori, 2017).

Hukum transendental sebagai paradigma hukum Indonesia dapat diletakkan dalam kerangka menjaga kepercayaan dan ekspektasi masyarakat agar tetap pada keyakinannya tentang keutuhan Indonesia. Penalaran rasionalitas dan koneksivitas batiniah yang dimiliki manusia menuntut ritme kesadaran akan kebenaran ilmu pengetahuan. Dalam ha ini hukum tidak hanya bersifat mengatur dan ditetapkan penguasa Negara tetapi menyangkut juga hukum yang hidup dan berkembang dari perilaku masyarakat yang sarat dengan niai nilai (Absori \& Achmadi, 2017).

Disamping itu dibutuhkan adanya moral dalam hukum dengan mendasarkan pada paradigma transendental yang mendasarkan pada nilai nilai ilahiyah (Dimyati, dkk., 2017). Dimensi transendental dalam Pancasila digambarkan dalam penentuan sila Pertama yang merupakan penegasan terhadap konsep tauhid deklarasi Ketuhanan (Ilahiah) yang mempercayai tidak ada Tuhan selain Tuhan Yang Maha Esa (Allah SWT), meskipun bunyi Pancasila mengalami perbedaan dengan Piagam Jakarta, namun perdebatan keduanya telah usai dan konsep tauhid disepakati menjadi sila pertama dalam Pancasila. Penentuan konsep tauhid dalam sila Pertama Pancasila menunjukkan bahwa Pancasila sebagai staatsfundamentalnorm sangat religius (Rustamaji, 2017). Pandangan Barda Nawawi Arief (2012) yang dikutip oleh Muhammad Rustamaji menyebutkan bahwa derivasi sila Pertama Pancasila menginspirasi tata hukum nasional menuju Biomijuridika.

Pancasila akan mempengaruhi seluruh instrumen hukum dibawahnya, Pancasila merupakan identitas dalam sistem hukum nasional dan ideologi bangsa. Ideologi memberi kita hal-hal ideal untuk diyakini, tujuan untuk diusahakan dan alasan untuk diperjuangkan. Fungsi penting lain dari ideologi adalah membentuk identitas kelompok yang majemuk atau bangsa. Ideologi memberikan kecenderungan untuk memisahkan kita (in group) dan mereka (out group), dengan demikian Ideologi berfungsi menyatukan (Pudyastungkoro, 2010).

Dalam dinamika kehidupan masyarakat Pancasila sebagai cita hukum akan berfungsi sebagai asas umum yang mempedomani, norma kritik dan faktor yang memotivasi dalam penyelenggaraan hukum (pembentukan, penemuan dan penerapan hukum) dan perilaku hukum (Absori, 2017). Dominasi positivisme mempengaruhi ketertundukan regulasi terhadap nilai-nilai dalam Pancasila, akbiatnya ruh dan semangat dalam Pancasila tidak terefleksi dalam regulasi dibawahnya, Pancasila diletakkan dalam singgasana tata aturan tertinggi yang tak mengalir pengaruhnya terhadap peraturan dibawahnya, hukum Indonesia pun menjelma tanpa identitas, liar tak terarah.

Ekonomi kerakyatan adalah sistem ekonomi yang lahir dengan nilai dan paradigma Pancasila. Menurut Natonagoro sebagaimana dikutip oleh Sinung Mufti Hangabei membedakan nilai menjadi tiga macam, yaitu nilai material, yaitu segala sesuatu yang 
berguna bagi kehidupan jasmani manusia, nilai vital, yaitu segala sesuatu yang berguna bagi manusia untuk dapat mengadakan kegiatan atau aktivitas dan nilai kerohanian, yaitu segala sesuatu yang berguna bagi rohani manusia. Nilai-nilai Pancasila oleh Natonagoro digolongkan sebagai nilai-nilai kerohanian, tetapi mengakui adanya nilai material dan nilai vital (Hangabei, 2017).

Jimly Asshiddiqie menyebutkan bahwa UUD 1945 mengandung gagasan demokrasi politik sekaligus demokrasi ekonomi. Artinya, dalam pemegang kekuasaan tertinggi di negara kita adalah rakyat, baik di bidang politik maupun di bidang ekonomi. Dalam konteks bernegara, kedaulatan rakyat bersifat relatif mutlak, meskipun harus diberi makna yang terbatas sebagai perwujudan ke-Maha-Kuasaan Allah sebagaimana diakui dalam Alinea Ketiga Pembukaan UUD 1945, sebagai konsekuensi Tauhid yaitu keimanan bangsa Indonesia kepada Allah SWT, Tuhan Yang Maha Esa, maka setiap manusia Indonesia dipahami sebagai khalifah Tuhan di atas muka bumi yang diberi kekuasaan untuk mengolah dan mengelola alam kehidupan untuk sebesar-besarnya kemakmuran bersama (Asshiddiqie, 2010).

Konstitusi kita memuat tujuan-tujuan kehidupan (politik dan ekonomi) dalam bingkai transendental, mengacu pada kepercayaan akan adanya Tuhan, demokrasi ekonomi pun bertujuan untuk menebarkan kemaslahatan. Apabila kita perhatikan, nilai dannorma dalam konstitusi semua bertujuan untuk menciptakan maslahat, membangun kebaikan dalam komunitas negara dan kehidupan, nilai tersebut senafas dengan kandungan QS. Al Anbiya: 107: "Dan Kami tidak mengutus engkau (Muhammad) melainkan untuk (menjadi) rahmat bagi seluruh alam".

Ungkapan 'rahmat bagi seluruh alam' dalam ayat di atas diartikan dengan kemasalahatan umat. Dalam kaitan ini para ulama sepakat, bahwa memang hukum syara' itu mengandung kemaslahatan untuk umat manusia (Syarifuddin, 1999).

Pasal 33 ayat (3) UUD 1945 menyebutkan bahwa penguasaan negara atas bumi, air dan kekayaan alam yang terkandung di dalamnya ditujukan sebesar-besarnya untuk kemakmuran rakyat, terminologi 'kemakmuran rakyat' dalam Pasal ini adalah semata-mata untuk kemaslahatan rakyat.

Al-Syatibi melihat kemaslahatan dari dua sudut pandang, yaitu (1) maqasid al-syari' (tujuan Tuhan), dan (2) maqasid al-mukallaf (tujuan mukallaf). Maqasid al-syari'ah dalam arti maqasid al-Syari', mengandung empat aspek, yaitu:

a. Tujuan awal dari syariat yakni kemaslahatan manusia di dunia dan di akhirat.

b. Syariat sebagai sesuatu yang harus dipahami.

c. Syariat sebagai suatu hukum takfif yang harus dilakukan, dan

d. Tujuan syariat adalah membawa manusia ke bawah naungan hukum (al-Syatibi, 2003).

Apabila kita kaitkan kemaslahatan dari sudut pandang Maqasid Al-Syari'menurut AlSyatibi, maka hal tersebut mengukuhkan transendensi Pancasila yang ingin mentransformasikan sistem politik, ekonomi, hukum dan sistem bernegara secara keseluruhan ke dalam nilai-nilai Ilahiah dan melepaskan diri dari pengaruh sekularisme hukum yang dibawa oleh Penjajah selama beratus-ratus tahun dengan supremasi Ketuhanan sebagai bingkainya. 


\section{Ekonomi Kerakyatan dan Konsep Transendental Kuntowijoyo}

Positivisme yang melahirkan demokrasi sebagai sistem politik memberikan kewenangan pada politik untuk membentuk hukum, sehingga hukum otomatis terpengaruh oleh politik, karena subsistem politik memiliki konsentrasi energi yang lebih besar daripada hukum (Mahfud MD, 2017). Konfigurasi politik pada saat perumusan Pancasila dan UUD 1945 didominasi oleh dua arus pemikiran yaitu nasionalis sekuler dan nasionalis Islam. Pancasila merupakan kompromi dari dua kelompok tersebut, namun kelompok nasionalis Islam berhasil memperjuangkan Nilai Ketuhanan sebagai Sila Pertama dalam Pancasila. Ekonomi kerakyatan dengan nama lainnya demokrasi ekonomi bukanlah konsep yang lahir dari positivisme sebagaimana diterapkan di negara-negara demokratis lainnya, karena sebagaimana dijelaskan diatas ekonomi kerakyatan adalah sistem ekonomi yang menjadikan Keimanan kepada Allah SWT sebagai landasannya dan berorientasi pada kemaslahatan manusia sebagai Khalifah Tuhan di muka bumi (Yunus, 2018).

Makna transendental menurut Kuntowijoyo sebagaimana dikutip oleh Absori mendasarkan keimanan kepada Allah (Ali Imron:110) dengan mengenalkan ilmu profetik, berupa humanisasi (ta'muruna bil ma'ruf), liberasi (tanhauna anil mungkar) dan transendensi (tu'minuna billah). Dalam hal ini unsur transendensi harus menjadi dasar unsur yang lain dalam pengembangan ilmu dan peradaban manusia (Absori, 2017). Jimly Asshiddiqie menyebut Pasal 33 sebagai konstitusi ekonomi Indonesia. Demokrasi ekonomi disebutkan dengan tegas sebagai dasar penyelenggaraan ekonomi nasional.

Prinsip-prinsip dalam demokrasi ekonomi sebenarnya tidak lepas dari konsep ilmu profetik yang disampaikan oleh Kuntowijoyo, penulis mencoba mengelompokkan konsep profetik Kuntowijoyo dan prinsip demokrasi ekonomi dalam Pasal 33 ayat (4) UUD 1945 sebagai berikut:

Tabel 1. Konsep Profetik dan Prinsip Demokrasi Ekonomi Kuntowijoyo

\begin{tabular}{|l|l|}
\hline \multicolumn{1}{|c|}{ Konsep Profetik } & \multicolumn{1}{c|}{ Prinsip Demokrasi Ekonomi } \\
\hline Humanisasi (ta'muruna bil ma'ruf) & Kebersamaan, wawasan lingkungan \\
\hline Liberasi (tanhauna anil mungkar) & $\begin{array}{l}\text { Kemandirian, keseimbangan kemajuan dan kesatuan } \\
\text { ekonomi nasional }\end{array}$ \\
\hline transendensi (tu'minuna billah) & efisiensi berkeadilan \\
\hline
\end{tabular}

Pengelompokan diatas meneguhkan dimensi transendental dalam sistem ekonomi kerakyatan, mendasarkan pada nilai-nilai Tauhid (Ketuhanan) dalam Pancasila. Kuntowijoyo menyebutkan bahwa Al Quran dan Sunnah sebagai landasan bagi keseluruhan bangunan ilmu pengetahuan profetik, baik ilmu kealaman (Ayat Kauniyah) sebagai basis hukum-hukum alam, humaniora (Ayat Nafsiyah) sebagai basis makna, nilai dan kesadaran maupun ketuhanan (Ayat Qauliyah) sebagai basis hukum-hukum Tuhan (Kuntowijoyo, 2004).

Prinsip kebersamaan dan prinsip wawasan lingkungan dalam ekonomi kerakyatan adalah bentuk humasinasi (ta'muruna bil ma'ruf) sistem ekonomi kerakyatan yang berasal dari pengembangan ayat Kauniyah, menginginkan kesejahteraan tidak hanya terpusat pada kelompok-kelompok tertentu, mencita-citakan kesejahteraan kolektif dan tidak individualistik. Prinsip kemandirian, prinsip keseimbangan kemajuan dan kesatuan ekonomi nasional adalah bentuk liberasi (tanhauna anil mungkar) sistem ekonomi dari pengembangan Ayat Nafsiyah, membangun bangsa yang mandiri dengan mengoptimalkan potensi dalam 
negeri namun tidak tertutup, tidak memungkiri keberadaan Indonesia sebagai salah satu bagian dari komunitas dunia sehingga kebijakan ekonomi mikro perlu memperhatikan ekonomi makro.

Prinsip efisiensi berkeadilan merupakan bentuk transendensi (tu'minuna billah) sistem ekonomi yang dikembangkan dari Ayat Qauliyah, memperhatikan prinsip efisiensi (menghindari tujuan yang sia-sia/ mubadzir) dan keadilan yang merupakan nilai universal yang wajib dimiliki oleh umat Islam karena merupakan salah satu akhlak mulia (akhlak alkarim), dalam Al Quran banyak ayat yang memerintahkan untuk berlaku adil (al'adl) dan adil merupakan salah satu sifat Allah SWT dalam Al Asmaul Husna. Hukum transendental dalam konteks Indonesia tidak boleh lepas dari dasar yang terdapat pada ideologi negara berupa Pancasila (Absori, 2016).

Inti Pancasila yang terdiri dari lima sila, berupa Ketuhanan, kemanusiaan, persatuan, kerakyatan dan keadilan. Menurut Bapak pendiri bangsa Soekarno inti Pancasila kalau diperas jadi gotong royong. Dalam bidang hukum, manifestasi dari ideologi Pancasila terjabarkan dalam cita hukum Pancasila yang berfungsi sebagai fondasi dan arah dari pembangunan dan pengembangan hukum nasional. Mengutip pendapat Absori bahwa hukum bersendikan Pancasila bertolak pada pandangan hidup bangsa Indonesia yang berkeyakinan bahwa alam semesta dengan segala isinya, termasuk harmonis diciptakan oleh Tuhan (Absori, 2016).

Absori berpendapat bahwa pengembangan hukum di Indonesia terdapat pijakan yang mendasari nilai-nilai transendental yakni ideologi negara Pancasila, Pembukaan Konstitusi UUD 1945 yang memuat bahwa proklamasi kemerdekaan Indonesia adalah atas berkat Rakhmat Allah Yang Maha Kuasa. Pembukaan UUD 1945 merupakan kesepakatan kokoh (mitsaqon gholidon) para pendiri bangsa yang menjadi dasar bangunan negara yang merupakan pengejawantahan cita-cita bangsa (Absori, 2017). Lebih lagi diatur jaminan kebebasan beragama menunjukkan spiritualitas konstitusi, Pasal 29 UUD 1945 menyebutkan bahwa negara berdasarkan atas Ketuhanan Yang Maha Esa. Negara menjamin kemerdekaan tiap-tiap penduduk untuk memeluk agamanya masing-masing dan beribadah menurut agamanya dan kepercayaannya itu.

\section{Kapitalisme Implementasi Ekonomi Kerakyatan}

Hegemoni demokrasi liberal yang dikembangkan di Amerika menghasilkan implementasi demokrasi Pancasila yang tidak sesuai dengan cita-cita awalnya. Demokrasi saat ini secara politik mulai mengalami pergeseran, tidak hanya masalah keterwakilan, namun identik dengan kapitalisasi politik yang menghasilkan politik transaksional, hal tersebut merupakan penyimpangan nilai-nilai dalam demokrasi Pancasila. Konfigurasi politik demokratis transaksional yang identik dengan politik biaya tinggi memunculkan investor politik kemudian mempengaruhi sistem ekonomi yang tidak lagi berorientasi pada kemaslahatan rakyat.

Kepanikan para kapitalis terhadap eksistensi transendensi Pancasila melalui terefleksinya paradigma Pancasila dalam norma-norma hukum positif sebagai turunannya memunculkan wacana mengevaluasi campur tangan negara dalam ekonomi, seperti dominasi negara dalam sektor ekonomi melalui BUMN tentu membuat kekhawatiran bagi para 
kapitalis. Krisis perekonomian dunia membangkitkan kepercayaan ditengah khalayak dari hampir semua aliran politik bahwa hanya kapitalisme yang diregulasi yang memiliki kesempatan untuk bertahan (Kellermann, 2016).

Literatur ilmu hukum mengenal kedaulatan (sovereignty) sebagai kekuasaan tertinggi dalam negara. Jean Bodin mengemukakan bahwa kedaulatan adalah kekusaan tertinggi untuk menentukan hukum dalam suatu negara yang sifatnya tunggal, asli, abadi dan tidak terbagibagi (Soehino, 2000). Dalam prinsip negara demokrasi, kedaulatan berada di tangan rakyat, termasuk kedaulatan ekonomi harus ditangan rakyat. Teori kedaulatan tersebut oleh Jean Bodin diistilahkan sebagai Kedaulatan Rakyat, kekuasaan tertinggi yang berada di tangan rakyat atau kita kenal sistem ini dengan sistem demokrasi yang merupakan turunan dari pemikiran positivistik yang diimplementasikan dalam kehidupan sistem politik.

Hasil penelitian Amos J. Peaslee menyebutkan bahwa dari 83 konstitusi negaranegara di dunia 90\% menganut prinsip kedaulatan rakyat (Peaslee, 1950), oleh karena banyaknya penganut kedulatan rakyat (demokrasi), bentuk demikian dianggap sebagai sistem yang paling ideal untuk sebuah negara hingga saat ini (Asshiddiqie, 2005). Jimly Asshiddiqie dalam bukunya Konstitusi dan Konstitusionalisme Indonesia menyebutkan bahwa kekuasaan di bidang politik dan kekuasaan di bidang ekonomi dapat dibedakan satu sama lain, akan tetapi memiliki hubungan fungsional yang erat satu sama lain (Asshiddiqie, 2005).

Demokrasi transaksional secara politik menjadi penyebab kapitalisasi ekonomi kerakyatan, akhirnya pembangunan ekonomi nasional tidak lagi memperhatikan kesejahteraan kolektif namun lebih berpihak pada kelompok-kelompok investor politik pendukung penguasa. Menurut Soeharsono Sagir, perekonomian setiap negara pasti berjalan menurut sistem tertentu. Jenis sistem ekonomi yang dianut Indonesia sebagai landasan pembangunan adalah sistem ekonomi kerakyatan (Sagir, 2009). Dalam sistem ini kedaulatan di bidang ekonomi ada di tangan rakyat, dan karena itu gagasan demokrasi ekonomi yang tidak lain ialah paham kedaulatan rakyat di bidang ekonomi.

Jimly Asshiddiqie berpendapat bahwa sasaran dari sistem ekonomi kerakyatan adalah pembebasan kehidupan rakyat dari kemiskinan, kebodohan, ketergantungan, perlakuan tidak adil, kerusakan lingkungan dan rasa was-was dalam menatap masa depan (Asshiddiqie, 2010). Karena itu kebijakan ekonomi nasional seharusnya tidak keluar dari asas ekonomi kerakyatan yang menurut Soeharsono Sagir tercermin dalam prinsip triple track development, yaitu pro-poor, pro-job dan pro-growth (Sagir, 2009).

Dalam mengimplementasikan ketiga prinsip tersebut ada enam tolak ukur yang dapat dipakai untuk menilai berhasil-tidaknya suatu proses pembangunan, yaitu:

a. Rakyat bebas dari kemiskinan dengan laju pertumbuhan ekonomi yang berkualitas;

b. Rakyat bebas dari kebodohan dn terberdayakan menjadi sumber daya insani (human capital) yang produktif;

c. Rakyat bebas dari pengangguran dengan bekerja kreatif dan produktif untuk meningkatkan penghasilan sendiri dan orang lain;

d. Negara bebas dari ketergantungan utang luar negeri;

e. Negara bebas dari kekurangan devisa karena nilai ekspor melebihi impor; dan

f. Negara bebas dari kerusakan ekosistem sehingga pembangunan dapat dikembangkan secara berkelanjutan. 


\section{KESIMPULAN}

Setiap hukum yang dibentuk harus berlandaskan Pancasila. Sistem politik dan sistem ekonomi-pun harus merefleksikan nilai-nilai Pancasila sebagai staats fundamental norm, Pancasila adalah ideologi dan cita hukum yang dipilih dan disepakati oleh bangsa Indonesia sehingga nilai dan paradigma yang terkandung didalamnya harus terefleksikan dalam regulasi dibawahnya, hal ini adalah keniscayaan sehingga sistem hukum, sistem politik maupun sistem ekonomi di Indonesia memiliki arah, pedoman dan panduan yang jelas. Sekulerisme sistem ekonomi dengan mengabaikan Pancasila membuat sistem ekonomi di Indonesia liar tak terarah, kehilaingan nilai, identitas dan semangat berbangsa yang akhirnya harus jatuh pada dominasi positivisme dan kembali pada pengaruh hukum Eropa Kontinental sebagaimana jaman penjajahan dahulu. Ini adalah bukti nyata betapa kemerdekaan belum sepenuhnya dimaknai dengan kemerdekaan menentukan ideologi bernegara, akhirnya upaya founding fathers dalam menyusun konsep Pancasila sebagai ideologi bangsa hanya menjadi retorika tertulis belaka yang tak implementatif.

Nilai-nilai dan paradigma Pancasila belum terefleksikan dalam sistem ekonomi, politik maupun sistem hukum nasional. Kapitalisme sistem ekonomi mengedepankan kepentingan pasar dan hanya berorientasi pada paradigma material sebagai rangkai bagan dari aliran positivisme dengan segenap persoalan dan ketidaksesuainnya dengan Pancasila. Dimensi transendental dalam Pancasila perlu digali, direfleksikan dalam sistem ekonomi nasional, sehingga kedaulatan rakyat sebagai mahluk dan Khalifah Allah SWT di muka bumi yang kelak akan mempertanggung jawabkan segala perbuatnnya (transendental) untuk kesimbangan (liberasi) dan kemanusiaan (humanisasi) sebagai salah nilai dan semangat yang dikembangkan oleh Pancasila dapat diimpelmentasikan.

\section{DAFTAR PUSTAKA}

Absori. (2017). Pemikiran Hukum Transendental dalam Konteks Pengembangan Ilmu Hukum Indonesia.

Absori. (2016). Cita Hukum Pancasila, Ragam Paradigma Hukum Berkepribadian Indonesia. Surakarta: Pustaka Iltizam.

al-Syatibi, A. I. (2003). Al-Muwafaqat fi Usủl al-Syaru’'ah. Bayrut: Dar Kutub al-'Ilmiyyah.

Arief, B. N. (2012). Pembangunan Sistem Hukum Nasional. Semarang: Pustaka Magister.

Asshiddiqie, J. (2005). Konstitusi dan Konstitusionalisme Indonesia. Jakarta: Konstitusi Press.

Asshiddiqie, J. (2010). Konstitusi Ekonomi. Jakarta: Kompas Gramedia.

Dimyati, K., Absori, A., Wardiono, K., \& Hamdani, F. (2017). Morality and law: Critics upon HLA Hart's moral paradigm epistemology basis based on prophetic paradigm. Jurnal Dinamika Hukum, 17(1), 23-30.

Djohansyah. (2008). Reformasi Mahkamah Agung menuju Independensi Kekuasaan Kehakiman. Jakarta: Kesaint Blanc.

Hangabei, S. M. (2017). Akar Transendensi Pancasila Dalam Hukum. Transendensi Hukum Prospek dan implementasi.

Jumadi, J. (2016). Akar Masalah Negara Hukum Indonesia, Prespektif Hermeneutika Hukum. Malang: UMM Pers.

Kellermann, S. D. H. (2016). Decent Capitalism. London: Fedrich Ebert Stiftung. 
Kementerian Agama Republik Indonesia. (2010). Al Quran dan Terjemahannya. Jakarta: Kementerian Agama RI.

KPPU. (2017). Komisi Pengawas Persaingan Usaha RI. Retrieved from: http://www.kppu.go.id/id/putusan

Kuntowijoyo. (2004). Islam Sebagai Ilmu: Epistimologi, Metodologi dan Etika. Jakarta: Mizan Publika.

Mahfud MD, M. (2016). BUMN Sebagai Tangan Demokrasi Ekonomi untuk Kesejahteraan Rakyat. Seminar Nasional dan Rakernas Federasi Serikat Pekerja Sinergi BUMN, 13 April.

Mahfud MD, M. (2017). Politik Hukum di Indonesia. Jakarta: Rajagrafindo Persada.

Nugroho, S. S. (2016). Pengembangan Epistimologi Ilmu Hukum Berbasis Transendental. Prespektif, XXI(1).

Pasaribu, P. (2015). Pendidikan Kewarganegaraan. Jakarta: Unimed.

Peaslee, A. J. (1950). Constitution of Nations. The Rumford Press.

Pudyastungkoro, D. (2010). Wawasan Kebangsaan, Pancasila dan Persatuan Bangsa. Jakarta: Kompas Gramedia.

Rustamaji, M. (2017). Menggali Akar Transendensi Pancasila Menuju Ilmu Hukum.

Yunus, A. (2018). Konsep dan Implementasi Ekonomi Kerakyatan dalam Prespektif Hukum Transendental. In Prosiding Seminar Nasional \& Call for Papers Hukum Transendental. 